\title{
UPAYA MENINGKATKAN HASIL BELAJAR SISWA MENGGUNAKAN MODEL PEMBELAJARAN COOPERATIVE TIPE Co-Op Co-Op PADA MATA PELAJARAN KIMIA
}

(Efforts to improve student learning outcomes using cooperative learning models type Co-Op Co-Op in chemical lessons)

\section{Armin Yunus}

Sekolah Menengah Atas Negeri 1 Randangan

Jl. Trans Sulawesi Motolohu, Kecamatan Randangan

Kabupaten Pohuwato, Provinsi Gorontalo, Kode Pos 96268

Email: arminyunus78@gmail.com

\begin{abstract}
ABSTRAK
Tujuan penelitian ini adalah untuk meningkatkan aktivitas belajar siswa Kelas $\mathrm{X}_{\mathrm{C}}$ SMA Negeri 1 Randangan melalui Model Pembelajaran Cooperative Tipe Co-Op dan untuk meningkatkan kemampuan siswa dalam kooperasi antara satu dengan yang lainnya dalam membahas sebuah materi di kelas. Penelitian ini merupakan penelitian tindakan kelas yang dilakukan secara kolaboratif antara guru/pengamat dengan peneliti. Subjek penelitian ini adalah siswa kelas $\mathrm{X}_{\mathrm{C}}$ SMA Negeri 1 Randangan yang berjumlah 28 siswa. Penelitian ini dilaksanakan dalam 2 siklus. Teknik pengumpulan data dengan observasi dan tes tertulis. Berdasarkan data diperoleh aktivitas guru meningkat,dari siklus I sebesar 73,80\% menjadi $100 \%$ terlaksana pada siklus II. Aktivitas siswa meningkat dari siklus I sebesar $66,66 \%$ menjadi $85,7 \%$ terlaksana pada siklus II. Data hasil evaluasi siklus I menunjukan bahwa siswa yang memperoleh nilai ketuntasan minimal 65 ke atas berjumlah 27 orang dari 38 siswa yang dikenakan tindakan atau $71,05 \%$,meningkat pada siklus II menjadi 33 orang atau 86,8\%. Jadi model pembelajaran kooperatif tipe Co-Op Co-Op dapat meningkatkan hasil belajar siswa kelas $\mathrm{X}_{\mathrm{C}}$ SMA Negeri 1 Randangan Kecamatan Randangan Kabupaten Pohuwato.
\end{abstract}

Kata Kunci: Model pembelajaran; tipe Co-Op Co-Op; kooperatif; hasil belajar.

\begin{abstract}
The purpose of this study was to improve the learning activities of Class XC students of SMA Negeri 1 Randangan through the Co-Op Co-Op type Cooperative Learning Model and to improve student's ability to cooperate in discussing the material in class. This research is classroom action research. The purpose of this study was to improve the learning activities of Class XC students of SMA Negeri 1 Randangan through the Co-Op Co-Op type Cooperative Learning Model and to improve student's ability to cooperate in discussing the material in class. This research is a classroom action research conducted collaboratively between teachers/observers and researchers. The subjects of this study were 28 students of class XC at SMA Negeri 1 Randangan. This research was conducted in 2 cycles- Data collection techniques with observation and written tests. Based on the data, it was found that teacher activity increased, from cycle I of $73.80 \%$ to $100 \%$ carried out in cycle II. Student activity increased from the first cycle of $66.66 \%$ to $85.7 \%$ in the second cycle. Data from the evaluation results of a cycle I showed that students who get a minimum completeness score of 65 and above are 27 of the 38 students who are subject to action or $71.05 \%$, increasing in the second cycle to 33 people or $86.8 \%$. So the Co-Op Co-Op type of cooperative learning model can improve student learning outcomes of class XC SMA Negeri 1 Randangan, Randangan District, Pohuwato Regency.
\end{abstract}

Keywords: Learning model; Co-Op Co-Op type; cooperative; learning outcome 


\section{PENDAHULUAN}

Fokus program pengajaran sains hendaknya ditujukan untuk memupuk minat dan pengembangan peserta didik terhadap dunia mereka di lingkungan mereka hidup. Pembelajaran dilakukan guru, khususnya pada pembelajaran kimia, selama ini masih menggunakan metode ceramah, sehingga pembelajaran hanya berfokus pada guru. Metode ini menyebabkan peserta didik tidak aktif selama proses pembelajaran, sehingga peserta didik tidak dapat mengembangkan materi yang seharusnya bisa dikembangkan melalui diskusi-diskusi dalam kelompok.

Permasalahan yang dihadapi di Kelas $\mathrm{X}_{\mathrm{C}}$ SMA Negeri 1 Randangan Kabupaten Pohuwato, khususnya pembelajaran Kimia adalah kurangnya partisipasi dan respon peserta didik pada proses pembelajaran. Hal ini nampak pada kurangnya perhatian peserta didik pada saat guru menjelaskan, kurangnya kemampuan peserta didik dalam memecahkan soal-soal latihan, rendahnya hasil yang dicapai peserta didik pada evaluasi, serta kurangnya kemauan peserta didik untuk mengajukan pertanyaan maupun menjawab pertanyaan yang diajukan guru. Keadaan tersebut berpengaruh pada hasil ulangan harian yang diperoleh peserta didik, yang berimbas pada ketuntasan hasil belajar yang tidak sesuai dengan kriteria ketuntasan yang telah ditetapkan.

Berdasarkan data hasil ulangan harian kelas Xc tahun pelajaran 2018/2019 tidak sesuai dengan kritera ketuntasan yang ditetapkan yakni 65, dari 40 siswa kelas Xc yang mengikuti ulangan harian hanya 15 orang atau 37,5\% yang nilainya mencapai standar ketuntasan yang ditetapkan. Halini disebabkan oleh kurangnya motivasi dan keaktifan peserta didik dalam belajar. Proses pembelajaran menggunakan metode ceramah menyebabkan peserta didik menjadi bosan dalam menerima pelajaran, sehingga berdampak pada hasil belajar yang dicapai oleh peserta didik.

Berdasarkan uraian diatas, maka dilakukan penelitian tindakan kelas dengan judul : "Upaya MeningkatkanHasil Belajar Siswa Menggunakan Model Pembelajaran Cooperative Tipe Co-Op Co-Op Pada Mata Pelajaran Kimia”.

Hipotesis dalam penelitian ini adalah sebagai berikut : "Jika digunakan model Pembelajaran Kooperatif tipe Co-op Co-op pada mata pelajaran kimia maka hasil belajar siswa akan meningkat". Adapun tujuan penelitian ini adalah untuk meningkatkan hasil belajar peserta didik kelas XcSMA Negeri 1 Randangan Kabupaten Pohuwato menggunakan model 
pembelajaran Co-op Co-op pada mata pelajaran Kimia.

\section{METODE PENELITIAN}

\section{Prosedur Penelitian}

Prosedur penelitian ini dilaksanakan dalam bentuk siklus pembelajaran dan mengacu pada prosedur penelitian tindakan kelas yang dilakukan Aqib (2009) yang terdiri dari : tahap Persiapan, dan tahap pelaksanaan tindakan. Pelaksanaan tindakan ini menggunakan dua siklus yaitu siklus I dan siklus II, tahap pemantauan dan evaluasi dan tahap analisis dan refleksi.

Penelitian tindakan kelas (PTK) ini dilaksanakan di SMA Negeri 1 Randangan. Tahun pelajaran 2018/2019. Penelitian ini mengikutsertakan 38 orang siswa kelas $\mathrm{X}_{\mathrm{C}}$ yang terdaftar pada semester genap tahun pelajaran 2018/2019 dengan rincian 19 orang laki-laki dan 19 orang perempuan.

\section{HASIL DAN PEMBAHASAN}

Hasil belajar pada kawasan kognitif berhubungan dengan hasil belajar yang pencapaiannya melalui pengetahuan dan keterampilan intelektual, sedangkan kawasan afektif berhubungan dengan hasil belajar yang pencapaiannya melalui minat/perhatian, sikap serta nilai-nilai. Kawasan psikomotor berhubungan dengan hasil belajar yang pencapaiannya melalui keterampilan manipulasi yang melibatkan otot dan kekuatan fisik. Untuk lebih memperdalam kajian hasil belajar kimia, dalam penelitian ini difokuskanpada hasil belajar Kimia pada kawasan kognitif.

Menurut Imron (2002), ranah kognitif terbagi atas 6 aspek, yaitu:

1. Pengetahuan

Dalam aspek ini, peserta didik hanya mengingat kembali fakta, konsep maupun prosedur yang telah dipelajari.

2. Pemahaman

Dalam aspek ini, dituntut untuk menggunakan kata-kata sendiri dalam mengemukakan pendapat atau gagasan, namun tetap merujuk pada pernyataan yang ada.

3. Aplikasi

Dalam aspek ini, peserta didik harus mampu menerapkan fakta, konsep gagasan dalam situasi khusus atau konkrit yang baru.

4. Analisis.

Aspek ini peserta didik mampu untuk merinci, menghubungkan, menguraikan rincian dan saling berhubungan antara bagian satu dengan bagian lainnya.

5. Sintesis.

Aspek ini dapat dimaknai sebagai suatu kemampuan untuk menyatukan hal-hal yang tidak menyatu menjadi suatu kesatuan yang utuh.

6. Evaluasi. 
Kemampuan mengadakan evaluasi ini

dalam

kawasan

kognitif. termasuk jenis kemampuan tertinggi

\section{HASIL DAN PEMBAHASAN}

Tabel 1. Hasil pengamatan aktivitas guru siklus I

\begin{tabular}{|c|c|c|c|c|c|c|c|c|}
\hline \multirow{3}{*}{ No } & \multicolumn{6}{|c|}{ Pertemuan } & \multirow{3}{*}{$\begin{array}{c}\text { Rata- } \\
\text { rata } \\
(\%)\end{array}$} & \multirow{3}{*}{ Kriteria } \\
\hline & \multicolumn{2}{|l|}{ I } & \multicolumn{2}{|l|}{ II } & \multicolumn{2}{|l|}{ III } & & \\
\hline & Jml Aspek & $\%$ & Jml Aspek & $\%$ & Jml Aspek & $\%$ & & \\
\hline 1 & 1 & 7,14 & 2 & 14,28 & 3 & 21,43 & 14,28 & SB \\
\hline 2 & 9 & 64,28 & 8 & 57,14 & 8 & 57,14 & 59,52 & B \\
\hline 3 & 4 & 28,58 & 4 & 28,58 & 3 & 21,43 & 26,2 & $\mathrm{C}$ \\
\hline
\end{tabular}

Tabel 2. Hasil pengamatan aktivitas siswa.

\begin{tabular}{|c|c|c|c|c|c|c|c|c|}
\hline \multirow{3}{*}{ No } & \multicolumn{6}{|c|}{ Pertemuan } & \multirow{3}{*}{$\begin{array}{c}\text { Rata- } \\
\text { rata } \\
(\%)\end{array}$} & \multirow{3}{*}{ Kriteria } \\
\hline & \multicolumn{2}{|l|}{ I } & \multicolumn{2}{|c|}{ II } & \multicolumn{2}{|l|}{ III } & & \\
\hline & Jml Aspek & $\%$ & Jml Aspek & $\%$ & Jml Aspek & $\%$ & & \\
\hline 1 & - & - & 1 & 7,14 & 2 & 14,28 & 7,14 & SB \\
\hline 2 & 8 & 57,14 & 9 & 64,28 & 8 & 57,14 & 59,52 & B \\
\hline 3 & 6 & 42,86 & 4 & 28,58 & 4 & 28,58 & 33,34 & $\mathrm{C}$ \\
\hline
\end{tabular}

Tabel 3. Hasil belajar siswa pada siklus I

$\begin{array}{cccc}\text { Rentang Nilai } & \text { Kriteria } & \begin{array}{c}\text { Jumlah } \\ \text { Siswa }\end{array} & \text { Presentase (\%) }\end{array}$

\begin{tabular}{clccc}
\hline $90-100$ & Sangat Baik & - & - & - \\
$75-89$ & Baik & 9 & 23,68 & Tuntas \\
$65-74$ & Cukup & 18 & 47,37 & Tuntas \\
& & & & Tdk Tuntas \\
$40-64$ & Kurang & 11 & $28,95 \%$ & - \\
$<40$ & Sangat Kurang & - & - &
\end{tabular}

Tabel 4. Hasil belajar siswa siklus II

\begin{tabular}{clccc}
\hline \multirow{2}{*}{ Rentang Nilai } & \multicolumn{1}{c}{ Kriteria } & Jumlah Siswa & Presentase $(\%)$ & Ketuntasan \\
& & & & \\
\hline $90-100$ & Sangat Baik & 16 & 10,5 & Tuntas \\
$75-89$ & Baik & 13 & 42,1 & Tuntas \\
$65-74$ & Cukup & 5 & 34,2 & Tuntas \\
$40-64$ & Kurang & - & 13,2 & Tidak Tuntas \\
$<40$ & Sangat kurang & - & \\
\hline
\end{tabular}


Berdasarkan pengamatan yang dilakukan, diperoleh bahwa proses pembelajaran yang dilaksanakan pada siklus II mengalami peningkatan dari siklus sebelumnya yaitu sebesar $100 \%$ aktivitas guru terlaksana dengan baik. Aktivitas siswa pun mengalami peningkatan menjadi $85,7 \%$ kriteria sangat baik $21,42 \%$ dankriteria baik 64,28\%, yang berarti mengalami peningkatan dibandingkan dengan siklus sebelumnya.

Pada siklus II terlihat juga adanya peningkatan hasil belajar yaitu sebesar $10,5 \%$ memperoleh hasil belajar dengan kriteria sangat baik, 42,1\% dengan krteria baik, 34,2\% dengan kriteria cukup. Dengan demikian ketuntasan siklus II adalah 33 siswa atau $86,8 \%$ dari 38 siswa yang dikenakan tindakan, dan hanya 5 siswa dengan kriteria kurang 13,2\% yang tidak tuntas hasil belajarnya atau memperoleh nilai dibawah 65 berdasarkan pemaparan diatas dapat disimpulkan bahwa pengamatan aktivitas guru dan aktivitas siswa, serta hasil belajar siswa memenuhi kriteria ketuntasan yang diharapkan, dalam hal ini indikator keberhasilan penelitian yang ditetapkan bahwa tindakan yang dilakukan telah berhasil dan tidak perlu lagi siklus berikutnya.

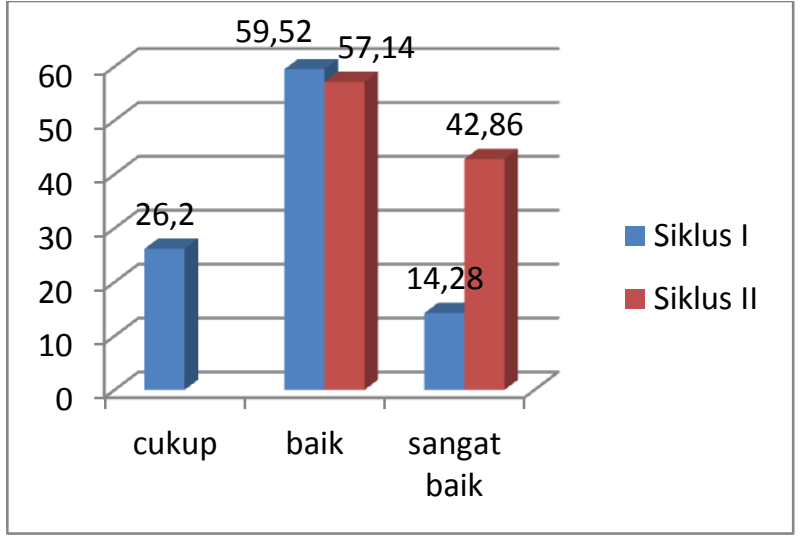

Gambar 1. Pengamatan aktivitas guru siklus I dan II

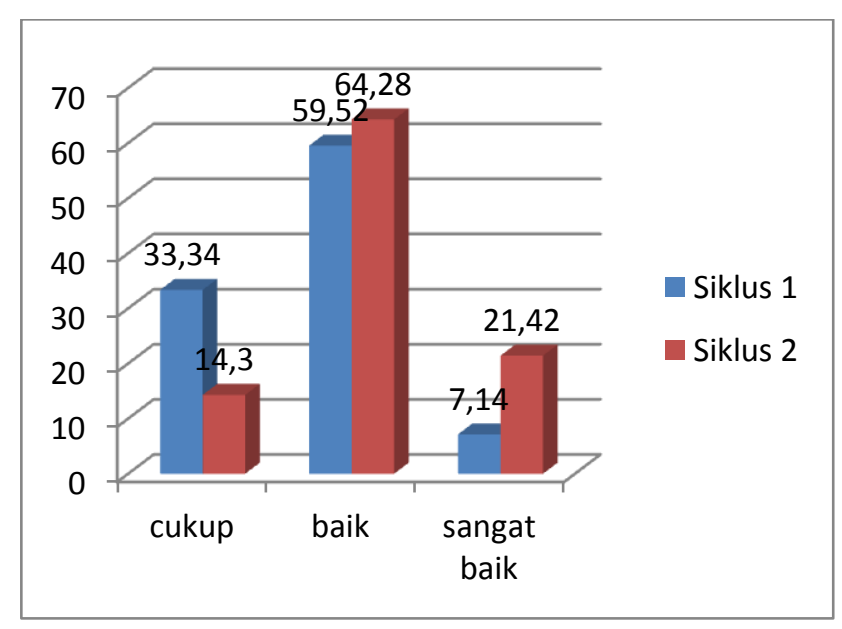

Gambar 2. Hasil pengamatan aktivitas siswa.

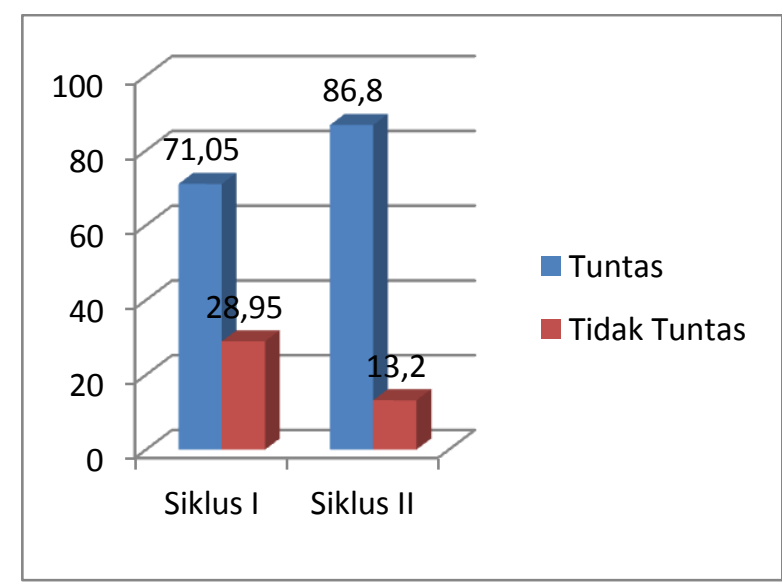

Gambar 3. Hasil belajar siswa siklus I dan siklus II 


\section{KESIMPULAN}

Berdasarkan data, analisis data dan pembahasan tentang upaya yang dilakukan untuk meningkatkan hasil belajar siswa menggunakan model pembelajaran kooperatif tipe co-op co-op dapat disimpulkan sebagai berikut :

1. Aktivitas guru meningkat,dari siklus I sebesar $73,80 \%$ menjadi $100 \%$ terlaksana pada siklus II.

2. Aktivitas siswa meningkat,dari siklus I sebesar $66,66 \%$ menjadi $85,7 \%$ terlaksana pada siklus II.

3. Data hasil evaluasi siklus I menunjukan bahwa siswa yang memperoleh nilai ketuntasan minimal 65 ke atas berjumlah 27 orang dari 38 siswa yang dikenakan tindakan atau 71,05\%,meningkat pada siklus II menjadi 33 orang atau $86,8 \%$.

Jadi model pembelajaran kooperatif tipe co-op co-op dapat meningkatkan hasil belajar siswa kelas X SMA Negeri 1 Randangan Kecamatan Randangan Kabupaten Pohuwato.

\section{DAFTAR PUSTAKA}

Aqib Z. 2009. Penelitian tindakan kelas. Bandung : Yrama Widya.

Depdiknas. 2002. Sosialisasi KTSP modelmodel pembelajaran efektif. Jakarta: Direktorat Jenderal Pendidikan Dasar dan Menengah Direktorat Sekolah Lanjutan Tingkat Pertama.
Imron, A. 2002. Belajar dan pembelajaran. Jakarta: Dunia Pustaka Jaya. 